\title{
A replacement name for a Philippine species of Actinodaphne (Lauraceae)
}

\author{
F. Brambach ${ }^{1} \&$ P.B. Pelser ${ }^{2}$ \\ ${ }^{1}$ Biodiversity, Macroecology and Biogeography, University of Göttingen, \\ Büsgenweg 1, Göttingen, Germany \\ fbrambach@uni-goettingen.de \\ ${ }^{2}$ School of Biological Sciences, University of Canterbury, \\ Private Bag 4800, Christchurch 8140, New Zealand
}

\begin{abstract}
We propose the replacement name Actinodaphne ramosii Brambach \& Pelser for Actinodaphne lanceolata (Merr.) Kosterm. ex Brambach \& Pelser, an illegitimate later homonym of Actinodaphne lanceolata Dalzell \& A.Gibson.
\end{abstract}

Keywords. Actinodaphne lanceolata, Actinodaphne ramosii, later homonym, Neolitsea, Philippines, taxonomy

\section{Introduction}

In transferring Neolitsea lanceolata Merr. (Merrill, 1919) to Actinodaphne, we unfortunately overlooked the fact that the new combination Actinodaphne lanceolata (Merr.) Kosterm. ex Brambach \& Pelser (Pelser et al., 2021) was illegitimate, being a later homonym of Actinodaphne lanceolata Dalzell \& A.Gibson (Dalzell and Gibson, 1861).

We regret this mistake and propose a replacement name for the species here.

\section{Replacement name}

Actinodaphne ramosii Brambach \& Pelser, nom. nov.

Neolitsea lanceolata Merr., Philipp. J. Sci. 14: 397 (1919). - Actinodaphne lanceolata (Merr.) Kosterm. ex Brambach \& Pelser, Blumea 66: 98 (2021), nom. illeg., non Actinodaphne lanceolata Dalzell \& A.Gibson (1861). - TYPE: Philippines, Catanduanes, Mt Mariguidon, 27 November 1917, BS (Ramos) 30231 (lectotype P [P00745221], designated by Pelser et al. (2021); isolectotypes A [A00042023], K [K000815482], PNH lost, US [US00099389]).

Distribution. Philippines (Catanduanes, Luzon). 
Eponymy. The name honours Maximo Ramos, who collected the type specimen of the species. Ramos, employed by the Bureau of Science at Manila, was one of the most prolific Philippine plant collectors of the early 20th century (Van Steenis-Kruseman \& Van Welzen, 2017).

\section{References}

Dalzell, N.E. \& Gibson, A. (1861). The Bombay flora: or, Short descriptions of all the indigenous plants hitherto discovered in or near the Bombay presidency: together with a supplement of introduced and naturalised species. Bombay: Education Society's Press.

Merrill, E.D. (1919). New or noteworthy Philippine plants, XV. Philippine J. Sci. 14: 365-457.

Pelser, P.B., Brambach, F., Mansibang, J., Schaefer, H., Kiew, R. \& Barcelona, J.F. (2021). New combinations and names for some Philippine vascular plants. Blumea 66: 96-100.

Van Steenis-Kruseman, M.J. \& Van Welzen, P.C. (2017). Cyclopaedia of Malesian Collectors. http://nationaalherbarium.nl/FMCollectors/. Accessed 2 Sep. 2021. 